\title{
Uncoupling the microbial loop: growth and grazing loss rates of bacteria and heterotrophic nanoflagellates in the North Atlantic
}

\author{
Thomas Weisse, Ulrike Scheffel-Möser \\ Limnological Institute, University of Constance, PO Box 5560, W-7750 Konstanz, Germany
}

\begin{abstract}
Growth and grazing loss rates of bacteria and heterotrophic nanoflagellates were investigated in the northeast Atlantic in spring 1989. Experiments were conducted in 2 different oligotrophic areas at $18^{\circ} \mathrm{N}, 30^{\circ} \mathrm{W}$ and at $33^{\circ} \mathrm{N}, 20^{\circ} \mathrm{W}$. Numbers of bacteria and protozoa, namely heterotrophic nanoflagellates (HNF), heterotrophic dinoflagellates and ciliates, were low in both areas, and the average abundance of microorganisms in the euphotic zone varied little. The microbial loop was uncoupled experimentally by differential filtration. Microplankton samples were size-fractionated by gravity filtration and changes in numbers of bacteria and their potential predators were measured in microcosms over several days. Maximum potential growth rates were $0.087 \mathrm{~h}^{-1}$ for bacteria and 0.123 $\mathrm{h}^{-1}$ for HNF. Ingestion rates ranged from 9 to 36 bacteria $\mathrm{HNF}^{-1} \mathrm{~h}^{-1}$, clearance rates ranged from 0.3 to $3.0 \times 10^{-5} \mathrm{ml} \mathrm{HNF}^{-1} \mathrm{~h}^{-1}$. Based on the experimental results, 3 modes of control of growth rates and abundances were identified - (1) substrate control: both bacteria and HNF did not grow unless substrates were added; (2) substrate and grazing control both effective: substrate supply via recycled dissolved organic matter enhanced bacterial growth moderately, followed by increasing HNF numbers which reduced the bacterial peak; (3) grazing control: bacterial production was balanced immediately by grazing protozoans, namely HNF, and removal of predators led to a pronounced bacterial peak. Results confirmed the hypothesis of a linear food chain consisting of bacteria - HNF - larger protozoa which is tightly coupled in the natural environment.
\end{abstract}

\section{INTRODUCTION}

It is well known from many laboratory studies that free-living bacteria have the potential for rapid growth, and turnover times of several hours have also been reported from various field studies (Williams 1981, Ducklow 1983, Pace 1988). Even if we assume that longer bacterial generation times of several days are more typical for the open ocean (Fuhrman et al. 1989), there must be mechanisms balancing bacterial growth since bacterial production does not result in continuously increasing bacterial biomass. Bacterial numbers usually vary less than one order of magnitude over the course of a year, a small range compared to the much larger seasonal fluctuations of the autotrophic picoplankton (Joint et al. 1986, Nagata 1990, Weisse \& Schweizer 1991), which is in the same size range as bacteria, and the larger phytoplankton and zooplankton (Wright \& Coffin 1984 and references therein). Bacterial 'blooms' are virtually unknown from oligotrophic and meso-eutrophic waters.

Among the factors that might control bacterial growth and production both in the sea and in lakes, substrate supply and grazing are currently considered to have the greatest potential (McManus \& Fuhrman 1988, Pace 1988, Wright 1988a, b, Güde 1989). Evaluation of the relative importance of these antagonistic processes is of special relevance in oligotrophic waters where bacterial population size varies little and appears to be in a quasi-steady state. Shifts in the major mode of control, substrate supply vs grazing, will, however, occur and temporarily disturb the steady state (Wright 1988a). Because the paradigm is basically qualitative rather than quantitative, knowledge of the control mechanism is essential for an understanding of the functioning of the microbial system (Wright 1988a). Other potential loss processes such as sedimentation, autolytic disintegration of senescent bacteria, lysis due to infection by lytic bacteria or bacteriophages, or mortality induced by allelopathic interactions are thought to be of minor importance or have not been described in planktonic bacteria (Güde 1986, McManus \& Fuhrman 1988, Pace 1988 and references therein). At present it cannot be estimated to what extent the recently 
discovered occasionally high abundance of viruses (Bergh et al. 1989, Bratbak et al. 1990, Proctor \& Fuhrman 1990) contributes to bacterial mortality in the open ocean.

This paper aims to assess the relative significance of substrate supply versus grazing control of bacterial growth rates and abundance in 2 similar oceanic environments. The simple experimental technique used, differential filtration of natural samples and subsequent incubation in microcosms, revealed the dominant control mechanisms and allowed quantification of growth and grazing rates of bacteria and their predators. Furthermore, the fate of the major bacterial consumers, heterotrophic nanoflagellates (HNF), could be evaluated. The size-fractionation technique was introduced into aquatic ecology by Wright \& Coffin (1984) and has since then repeatedly been used in studies focusing on predator-prey interactions in the microbial loop (Rassoulzadegan \& Sheldon 1986, Wikner \& Hagström 1988, Kuuppo-Leinikki 1990).

The present investigation was part of the pilot study within the Joint Global Ocean Flux Study (JGOFS) and was carried out aboard RV 'Meteor' (cruise No. 10/ 1989, $\operatorname{leg} 2$ ).

\section{MATERIAL AND METHODS}

The investigation was conducted in 2 areas of the central northeast Atlantic. In both areas, a drifting drogue was launched and followed over about 2 wk. Sampling was always close to the drogue. The first study area (26 March to 6 April 1989) was located at $18^{\circ}$ $\mathrm{N}, 30^{\circ} \mathrm{W}$, at the northern fringe of the northeast trade wind zone. Mixed layer depth ranged from 50 to $60 \mathrm{~m}$ with almost constant temperature of $21.8^{\circ} \mathrm{C}$ and salinity of $36.7 \%$. After 1 April, an intrusion of a slightly cooler water mass was observed in 60 to $70 \mathrm{~m}$ depth. Underneath, temperature was close to surface values and dropped at the permanent thermocline at about $110 \mathrm{~m}$ depth. Nutrient concentrations (soluble reactive phosphate, nitrate, nitrite, silicate) were below $0.2 \mu \mathrm{mol}$ $1^{-1}$ in the mixed layer. The northern investigation area (13 April to 24 April) at $33^{\circ} \mathrm{N}, 20^{\circ} \mathrm{W}$ was located in the eastern part of the subtropical gyre. Vertical gradients of temperature, salinity and density were very low within the upper $100 \mathrm{~m}$ of the water column. Average temperature was $17.6^{\circ} \mathrm{C}$, salinity $36.5 \%$. Nutrient concentrations were similarly low as in the southern study area. All hydrographic data were measured by $\mathrm{S}$. Podewski and G. Saure, and nutrients by R. Werner, all of IfM Kiel, Germany, and have been reported by Jochem (1990).

Niskin water bottle samples were taken from various depths from the upper $100 \mathrm{~m}$. The depths were chosen according to the fluorescence profile recorded prior to sampling. One subsample for bacteria, autotrophic picoplankton (APP) and HNF was fixed immediately with formalin (1.5\% vol/vol final concentration), another subsample for phytoplankton and larger protozoa with Lugol's solution (1 ml per $100 \mathrm{ml}$ sample). Bacteria, APP and HNF were enumerated using epifluorescence microscopy and DAPI staining (Porter \& Feig 1980). Phytoplankton and larger heterotrophic microorganisms, namely dinoflagellates and ciliates, were counted using inverted microscopy. The biomass and species composition of larger protozod will be reported elsewhere in detail (Scheffel-Möser et al. unpubl.).

For the experiments, samples were taken from the depth of the fluorescence maximum. Experiments were conducted in $250 \mathrm{ml}$ Erlenmeyer or Nuncion flasks. They started within $1 \mathrm{~h}$ after sampling and lasted for 98 to $151 \mathrm{~h}$. Experiments were run at the ambient temperature $\left( \pm 2^{\circ} \mathrm{C}\right)$ and at 30 to $45 \mu \mathrm{E} \mathrm{m}^{-2} \mathrm{~s}^{-1}$, which corresponded roughly to the ambient light intensity at the depths of the chlorophyll maximum (50 to $80 \mathrm{~m}$ ). Experimental conditions simulated the natural light/ dark rhythms if not stated otherwise. Larger plankton was excluded from the experimental bottles by gentle inverse pre-screening through $30 \mu \mathrm{m}$ and $10 \mu \mathrm{m}$ mesh gauze or by pre-filtering through $1.0 \mu \mathrm{m}$ Nuclepore filters (47 mm diameter) using gravity filtration. One set of experiments consisted of 4 different treatments: unfiltered, $<30 \mu \mathrm{m},<10 \mu \mathrm{m}$, and $<1 \mu \mathrm{m}$. Numbers of bacteria, APP, and HNF were measured in subsamples taken every 4 to $12 \mathrm{~h}$. HNF were counted separately in 4 size classes: $<2 \mu \mathrm{m}, 2-5 \mu \mathrm{m}, 5-10 \mu \mathrm{m}$ and $10-20 \mu \mathrm{m}$. The size of HNF was measured microscopically using an ocular grid. Initial HNF concentrations were generally too low to allow precise measurements of many $(>70)$ specimens over the entire size range. Therefore, a standard biovolume was calculated for each size class based on microscopic observations. Geometric measurements were converted to volume assuming geometric shapes of rotational ellipsoids with circular crosssections.

Heterotrophic dinoflagellates and ciliates were counted at the end of the experiments only because the larger sampling volume $(50 \mathrm{ml})$ needed for inverted microscopy did not allow more frequent measurements. They were enumerated in 11 size classes: 5-10 $\mu \mathrm{m}$, then in $10 \mu \mathrm{m}$ intervals up to $100 \mu \mathrm{m}$, and $>100 \mu \mathrm{m}$.

In the enclosure experiments, oscillations of the Lotka-Volterra-type predator-prey model between HNF and bacteria evolved. The corresponding equations were reported by Andersen \& Fenchel (1985): If $x(t)$ represents the bacteria at time $t$ and $y(t)$ represents $\mathrm{HNF}$, both populations will grow according to 


$$
\mathrm{d} x / \mathrm{d} t=x(t) \mu(x)-y(t) f(x)
$$

and

$$
\mathrm{d} y / \mathrm{d} t=y(t) Y f(x)-y(t) d
$$

where $\mu(x)=$ density-dependent growth rate of bacteria; $f(x)=$ bacterial ingestion rate of HNF (bacteria $\mathrm{HNF}^{-1} \mathrm{~h}^{-1}$ ); $Y=$ gross growth efficiency ('yield') of flagellates; and $d=$ density-independent death rate, i.e. the rate at which HNF die when starving. In the absence of predation, the second term in Eq. (1) can be neglected. Similarly, the death rate of HNF in Eq. (2) can be neglected if rates are evaluated before HNF grazing reduced bacterial concentrations below a critical threshold at which HNF begin to starve. In almost all experiments, bacteria and HNF exhibited a period of exponential increase:

$$
N_{t}=N_{o} \times \mathrm{e}^{\mu t}
$$

where $N_{0}=$ initial concentration and $N_{t}=$ final concentration after $t h$. During these periods, maximum growth rates $(\mu)$ were calculated by least squares linear regression of log-transformed data over at least 3 subsequent samplings. Bacterial ingestion rate $(I=f(x))$ and clearance rate $(C)$ of HNF were calculated according to

and

$$
\begin{gathered}
I\left(\text { bacteria } \mathrm{HNF}^{-1} \mathrm{~h}^{-1}\right)=\mu x / y \\
C\left(\mathrm{nl} \mathrm{HNF} \mathrm{HN}^{-1} \mathrm{~h}^{-1}\right)=I / x
\end{gathered}
$$

\section{RESULTS}

\section{Environmental parameters and vertical distribution of microorganisms}

In the southern investigation area, a fluorescence maximum was always recorded in intermediate depths (45 to $80 \mathrm{~m}$ ). Average chlorophyll a concentrations were about $0.3 \mu \mathrm{g} \mathrm{l}^{-1}$, maximum concentrations always well below $1 \mathrm{\mu g} \mathrm{l}^{-1}$ (data reported by Jochem 1990). Autotrophic picoplankton, mainly Synechococcus spp., comprised more than $75 \%$ of the total chlorophyll biomass. Eucaryotic picoplanktonic algae occurred with increasing numbers at the bottom of the euphotic zone but contributed little to the total picoplankton biomass in the upper $100 \mathrm{~m}$. The vertical distribution of bacteria, HNF and ciliates showed little relation to the APP maximum (Fig. 1). At Stns 241 and 266 the fluorescence profile peaked in 65 to $80 \mathrm{~m}$ (data not shown). In the northern area (Stns 332, 345, 358) the fluorescence profiles scattered more and the depth of the chlorophyll maximum was variable or no chlorophyll peak was apparent at all. Here, the contribution of APP to total chlorophyll was lower but always exceeded $55 \%$ (Jochem 1990). Similar to the southern area, the distribution of APP numbers paral-
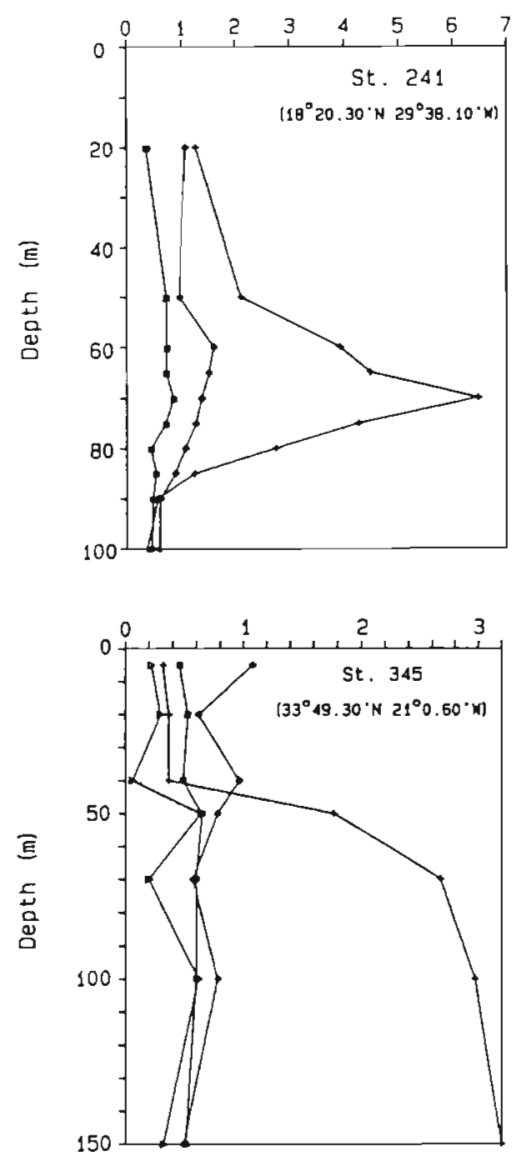
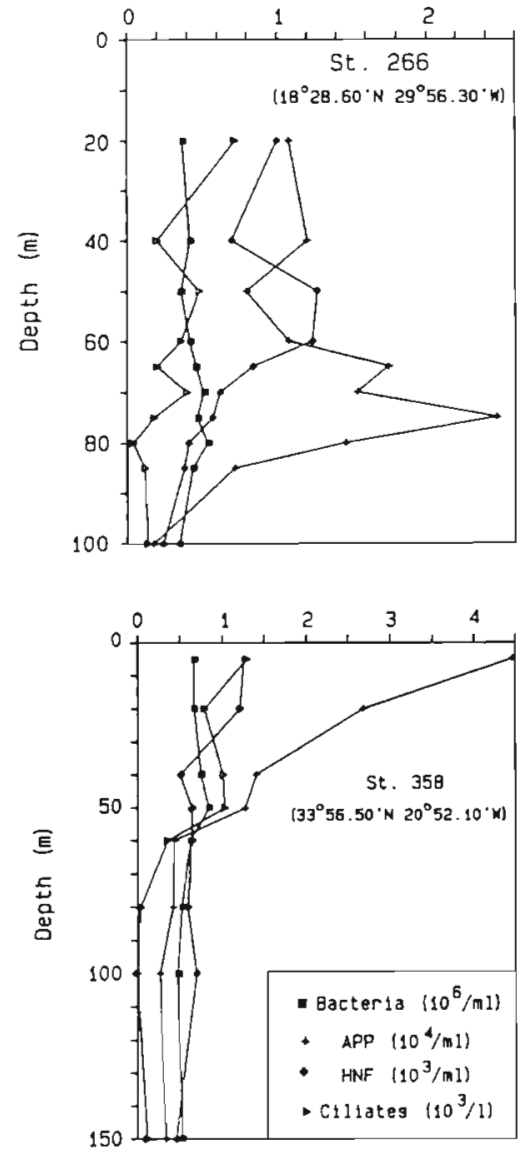

Fig. 1. Vertical distribution of pelagic microorganism in the southern investigation area (upper panel) and in the northern area (lower panel) 
leled the chlorophyll concentration. The vertical distribution of pelagic microorganisms did not show a clear pattern. At 2 stations $(332,358)$ numbers of APP and HNF were highest in near-surface waters and decreased with depth. At Stn 345, however, APP concentrations increased with depth whereas microheterotrophs were almost uniformly distributed in the upper $150 \mathrm{~m}$. Averaged over the upper $100 \mathrm{~m}$, the concentrations of bacteria and HNF were almost constant in both areas. Mean values for bacteria were $0.52 \pm 0.12(\mathrm{SD}) \times 10^{6}$ cells ml $\mathrm{m}^{-1}(\mathrm{n}=10)$ in the southern and $0.61 \pm 0.16 \times 10^{6}$ cells $\mathrm{ml}^{-1}(\mathrm{n}=5)$ in the northern area. The corresponding means for HNF were $0.86 \pm 0.23 \times 10^{3}$ cells $\mathrm{ml}^{-1}$ and $0.78 \pm 0.06 \times 10^{3} \mathrm{ml}^{-1}$ respectively.

\section{Experiments in the southern area}

The first enclosure experiment was conducted with water obtained at Stn 239 and run at the natural light/ dark rhythm and at temperatures ranging from 20.5 to $22.0^{\circ} \mathrm{C}$. Bacterial abundance increased in all experimental bottles over the first $24 \mathrm{~h}$ (Fig. 2). Maximal growth rates calculated during the period of exponential growth (between 4 and $24 \mathrm{~h}$ after the beginning of the experiment) were not statistically different in the $<1 \mu \mathrm{m}$ and the $<10 \mu \mathrm{m}$ pre-filtered samples. In the larger 2 fractions, bacterial growth rates were substantially reduced (Table 1). Accordingly, the bacterial peak was highest in the $<1 \mu \mathrm{m}$ sample and increas- ingly less expressed in the larger size fractions. Therefore, we assume that (1) bacteria were not substrate- or nutrient-limited at the onset of the experiments and (2) grazing largely prevented population increase in the unfiltered and $<30 \mu \mathrm{m}$ sample. In the smallest 2 fractions, grazing was apparently caused by HNF since larger organisms were absent. A predator-prey relationship of the Lotka-Volterra type between HNF and bacteria was most pronounced in the $<10 \mu \mathrm{m}$ experiment. Here, growth rates of HNF were highest and even exceeded those of bacteria (Table 1).

The HNF peak occurred in all fractions $2 \mathrm{~d}$ after the bacterial peak. Similar to bacteria, HNF growth rates were much lower in the 2 larger size classes. In all enclosures the HNF peak consisted of 1 or 2 chrysomonad species with longest linear dimensions of 4 to $5 \mu \mathrm{m}$. The initial concentration of HNF increased from the smallest to the largest compartment. There was also an apparent difference in the average cell size at the beginning of the experiments. The average biovolume was distinctly lower in the smallest size class because only the smallest HNF squeezed through the $1 \mu \mathrm{m}$ filter (Table 2). Therefore, the initial HNF biomass was considerably reduced in the $<1 \mu \mathrm{m}$ fraction compared to the larger size classes.

It is likely that HNF grazing largely balanced bacterial production from the very beginning and thus prevented pronounced bacterial peaks in the 2 larger size fractions. Bacterial consumption rates and clearance rates of HNF were calculated at the bacterial peak, at the HNF peak and $12 \mathrm{~h}$ before the HNF peak
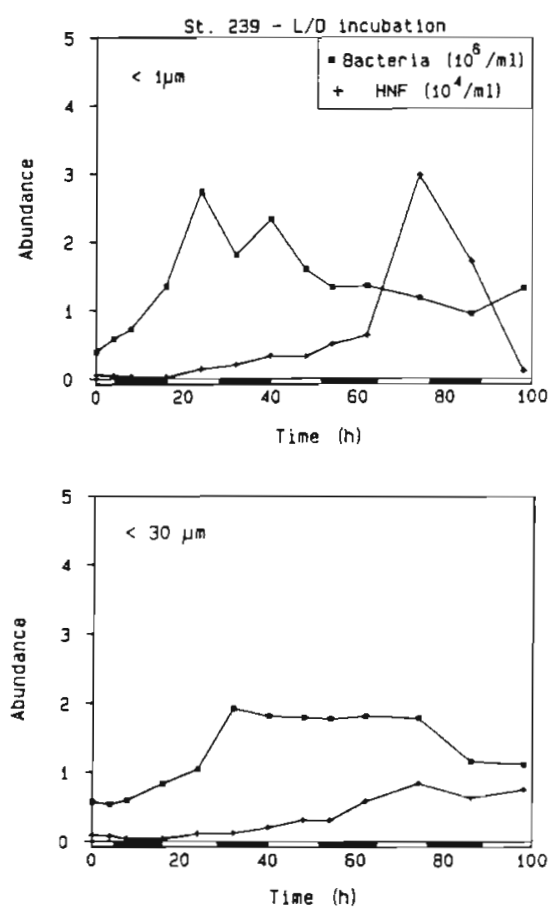
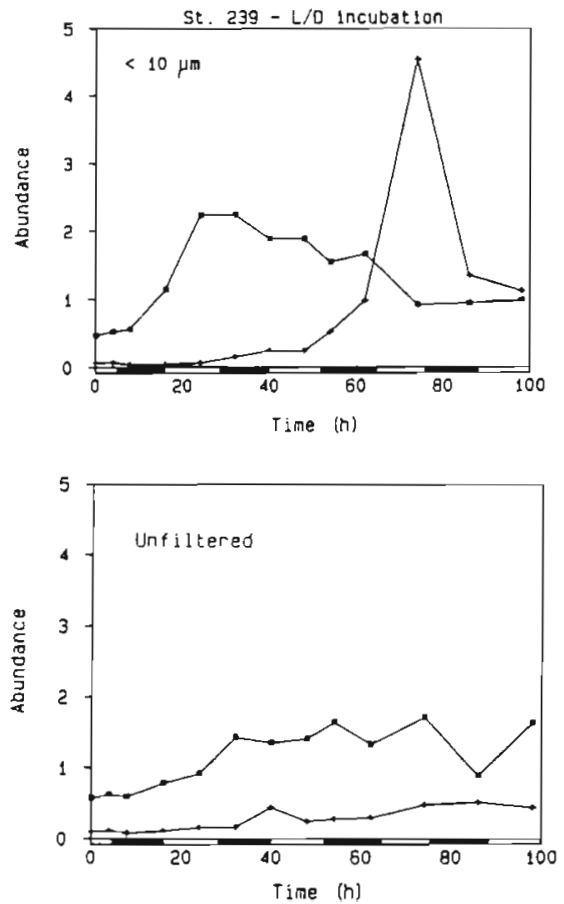

Fig. 2. Variation of bacterial and HNF numbers in experiments conducted at Stn 239 under natural light/dark rhythm (indicated below figures) 
(according to Andersen \& Fenchel 1985) (Table 3). As already noted by Andersen \& Fenchel, the first calculation may overestimate ingestion and clearance rates because there is a time lag before previously starved HNF cells can begin to divide. The second calculation, however, may underestimate the true values because HNF after starvation continue to divide once or twice (Fenchel 1982a, Andersen \& Fenchel 1985). Therefore, the calculation based on abundances measured $12 \mathrm{~h}$ before the HNF peak, which corresponded to about twice the average doubling time of HNF (cf. Table 1), is considered realistic. Ingestion and clearance rates of
HNF thus calculated (Table 3, columns C) were higher in the unfiltered enclosures than in pre-screened samples. This might indicate that HNF were not the sole consumers of bacteria during the experiments but that some bacterivory was due to larger microplankton. If so, values calculated for HNF ingestion and clearance in the unfiltered samples would be too high.

It is obvious that the high bacterial concentration of $2.2 \times 10^{6}$ cells $\mathrm{ml}^{-1}$ in the $<30 \mu \mathrm{m}$ bottle was not followed by a pronounced HNF peak. Therefore, HNF appeared to be grazed mainly by organisms in the 10-30 $\mu \mathrm{m}$ size range. After $98 \mathrm{~h}, 2.4 \times 10^{2} \mathrm{l}^{-1}$ dinoflagellates

Table 1. Maximum growth rates ( $\mu$ ) of bacteria and heterotrophic nanoflagellates (HNF) during the experiments conducted in the southern investigation area (Nos. 1 to 3 ) and in the northern investigation area (No. 4). Growth rates were calculated by linear regression of log-transformed data over the period of exponential increase (p: level of significance of correlation coefficient r; $G$ : doubling time). Only results are reported where the increase continued over at least 3 subsequent samplings

\begin{tabular}{|c|c|c|c|c|c|c|}
\hline \multirow[t]{2}{*}{ Expt } & \multicolumn{3}{|c|}{ Bacteria } & \multicolumn{3}{|c|}{ HNF } \\
\hline & $\mu\left(\mathrm{h}^{-1}\right)$ & $\mathrm{p}$ & $G(\mathrm{~h})$ & $\mu\left(\mathrm{h}^{-1}\right)$ & $\mathrm{p}$ & $G(\mathrm{~h})$ \\
\hline \multicolumn{7}{|l|}{ No. 1} \\
\hline$<1 \mu \mathrm{m}$ & 0.083 & $\cdot$ & 8.3 & 0.084 & $\cdot$ & 8.3 \\
\hline$<10 \mu \mathrm{m}$ & 0.086 & $\cdots$ & 8.0 & 0.112 & $\cdots$ & 6.2 \\
\hline$<30 \mu \mathrm{m}$ & 0.047 & $\cdot$ & 14.7 & 0.058 & $\cdots$ & 12.0 \\
\hline Unfilt. & 0.035 & $\cdot$ & 19.7 & 0.049 & $\cdot$ & 14.1 \\
\hline \multicolumn{7}{|l|}{ No. 2} \\
\hline$<1 \mu \mathrm{m}$ & 0.056 & $\cdot$ & 12.4 & 0.103 & $\cdot$ & 6.7 \\
\hline$<10 \mu \mathrm{m}$ & 0.039 & $\cdot$ & 17.8 & 0.103 & ns & 6.8 \\
\hline$<30 \mu \mathrm{m}$ & 0.027 & $\cdot$ & 25.5 & 0.064 & $\cdot$ & 10.8 \\
\hline Unfilt. & 0.030 & $\cdot$ & 22.9 & 0.028 & $\cdot$ & 24.5 \\
\hline \multicolumn{7}{|l|}{ No. 3} \\
\hline$<1 \mu \mathrm{m}$ & 0.049 & - & 14.0 & 0.087 & - & 7.9 \\
\hline$<10 \mu \mathrm{m}$ & 0.084 & $\cdot$ & 8.3 & 0.123 & $\cdot$ & 5.6 \\
\hline$<30 \mu \mathrm{m}$ & 0.094 & ns & 7.3 & 0.058 & $\cdots$ & 12.0 \\
\hline Unfilt. & 0.051 & ns & 13.6 & - & - & - \\
\hline \multicolumn{7}{|l|}{ No. 4} \\
\hline$<1 \mu \mathrm{m}$ & 0.051 & $\cdots$ & 13.6 & 0.068 & $\cdots$ & 10.2 \\
\hline$<10 \mu \mathrm{m}$ & 0.026 & $\cdot$ & 27.0 & 0.053 & $\cdot$ & 13.1 \\
\hline$<30 \mu \mathrm{m}$ & 0.086 & $\cdot$ & 8.1 & 0.044 & $\cdot$ & 15.7 \\
\hline Unfilt. & 0.016 & $\cdot$ & 42.3 & 0.064 & $\cdots$ & 10.8 \\
\hline \multicolumn{7}{|c|}{$\cdots$ Significant at $99.9 \%$ level } \\
\hline \multicolumn{7}{|c|}{ - Significant at $99 \%$ level } \\
\hline \multicolumn{7}{|c|}{ - Significant at $95 \%$ level } \\
\hline ns: not signi & & & & & & \\
\hline
\end{tabular}

Table 2. Average individual biovolume $\left(\mu \mathrm{m}^{3}\right)$ of heterotrophic nanoflagellates (HNF) at the beginning (B) of the experiments and at the HNF peak (P)

\begin{tabular}{|c|c|c|c|c|c|c|c|c|}
\hline \multirow[t]{2}{*}{ Expt no. } & \multicolumn{2}{|c|}{$<1 \mu \mathrm{m}$} & \multicolumn{2}{|c|}{$<10 \mu \mathrm{m}$} & \multicolumn{2}{|c|}{$<30 \mu \mathrm{m}$} & \multicolumn{2}{|c|}{ Unfiltered } \\
\hline & $\mathrm{B}$ & $\mathrm{P}$ & $\mathrm{B}$ & $P$ & $\mathrm{~B}$ & $\mathrm{P}$ & B & $\mathrm{P}$ \\
\hline 1 & 3.8 & 21.7 & 8.0 & 25.2 & 10.0 & 26.8 & 8.2 & 24.9 \\
\hline 2 & 3.1 & 25.1 & 7.1 & 26.0 & 9.1 & 24.3 & 4.8 & 23.5 \\
\hline 3 & 6.8 & 21.0 & 9.4 & 31.4 & 10.0 & 25.7 & 8.1 & 29.5 \\
\hline 4 & 5.5 & 30.3 & 8.8 & 29.5 & 8.4 & 27.1 & 15.1 & 30.9 \\
\hline
\end{tabular}


Table 3. Ingestion and clearance rates of heterotrophic nanoflagellates (HNF) calculated from the experimental results. Values were calculated at the bacterial peak (A), at the HNF peak (B) and $12 \mathrm{~h}$ before the HNF peak (C). Experimental numbers correspond to Figs. 2 to 4

\begin{tabular}{|c|c|c|c|c|c|c|}
\hline \multirow[t]{2}{*}{ Expt No. } & \multicolumn{3}{|c|}{ Ingestion rate (bact. $\mathrm{HNF}^{-1} \mathrm{~h}^{-1}$ ) } & \multicolumn{3}{|c|}{ Clearance rate (nl $\mathrm{HNF}^{-1} \mathrm{~h}^{-1}$ ) } \\
\hline & A & $\mathrm{B}$ & $C$ & A & $\mathrm{B}$ & $\mathrm{C}$ \\
\hline $1 /<1 \mu \mathrm{m}$ & 164 & 3 & 18 & 60 & 3 & 13 \\
\hline $1 /<10 \mu \mathrm{m}$ & 266 & 2 & 15 & 119 & 2 & 9 \\
\hline $1 /<30 \mu \mathrm{m}$ & 133 & 18 & 27 & 69 & 10 & 15 \\
\hline 1/Unfilt. & 72 & 14 & 39 & 50 & 16 & 29 \\
\hline $2 /<1 \mu \mathrm{m}$ & 150 & 4 & 6 & 62 & 3 & 3 \\
\hline $2 /<10 \mu \mathrm{m}$ & 138 & 5 & 27 & 68 & 3 & 14 \\
\hline $2 /<30 \mu \mathrm{m}$ & 80 & 15 & 16 & 52 & 10 & 11 \\
\hline 2/Unfilt. & 64 & 32 & 38 & 48 & 22 & 30 \\
\hline $3 /<1 \mu \mathrm{m}$ & 85 & 64 & 36 & 59 & 51 & 30 \\
\hline $3 /<10 \mu \mathrm{m}$ & 208 & 4 & 9 & 79 & 6 & 7 \\
\hline $3 /<30 \mu \mathrm{m}$ & 162 & 20 & 25 & 111 & 6 & 28 \\
\hline 3/Unfilt. & 190 & 46 & 66 & 175 & 51 & 52 \\
\hline $4 /<1 \mu \mathrm{m}$ & nd & nd & 10 & nd & nd & 9 \\
\hline $4 /<10 \mu \mathrm{m}$ & nd & nd & 10 & nd & nd & 7 \\
\hline $4 /<30 \mu \mathrm{m}$ & nd & nd & 26 & nd & nd & 29 \\
\hline 4/Unfilt. & nd & nd & 10 & nd & nd & 11 \\
\hline
\end{tabular}

(dominant genera Gymnodimium and Gyrodinium) and $2.4 \times 10^{2} \mathrm{l}^{-1}$ ciliates were found in the $<30 \mu \mathrm{m}$ container. These concentrations were in the range of values generally found in the southern investigation area. In the unfiltered enclosure, concentrations were lower with $1.2 \times 10^{2} 1^{-1}$ dinoflagellates and $0.4 \times 10^{2}$ $1^{-1}$ ciliates, respectively.
In parallel with the first experiment, a second experiment using the same water was run at the same temperature but in complete darkness. Results are shown in Fig. 3 and in Tables 1 to 3. Qualitatively, the changes in bacterial and HNF numbers were similar to the illuminated treatments. Maximal growth rates both of bacteria and HNF were, however, distinctly lower com-
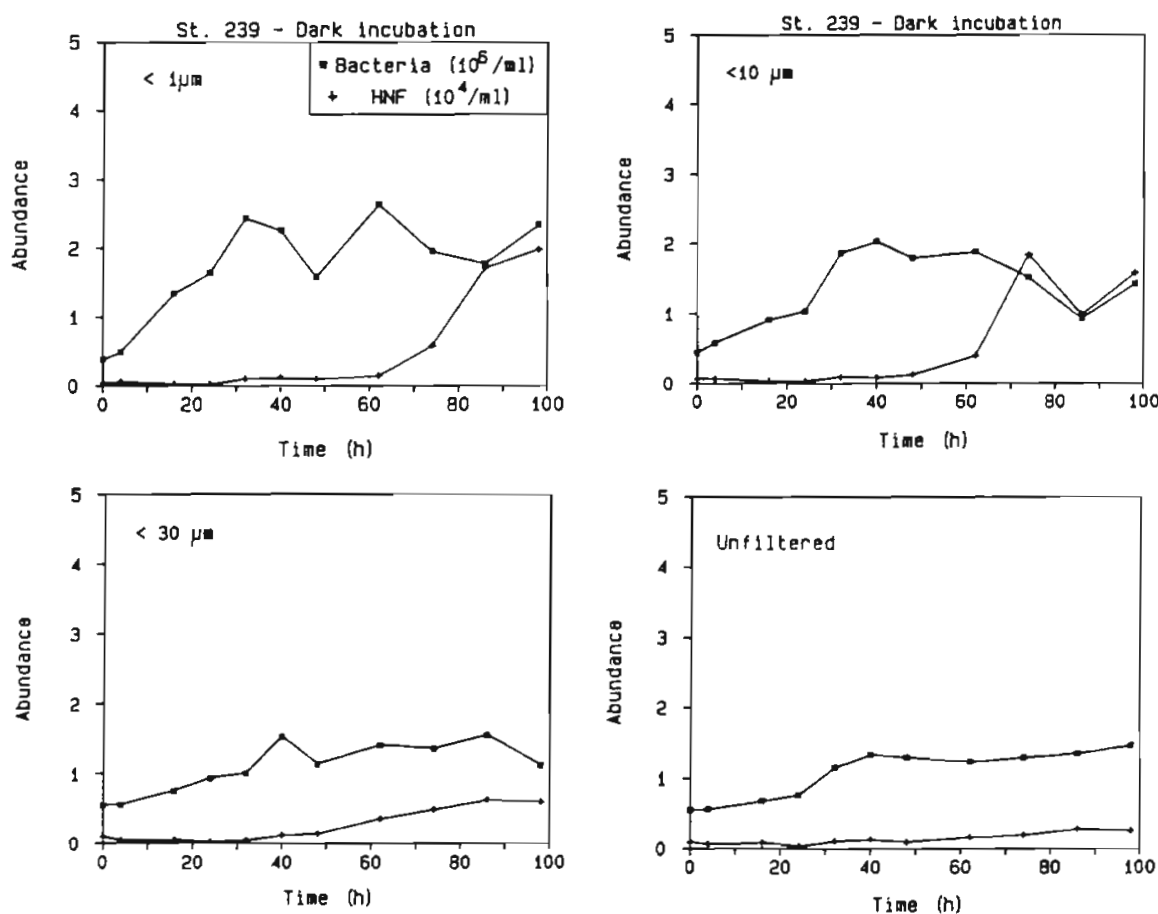

Fig. 3. Bacterial and HNF numbers in

Expt No. 2 conducted at Stn 239 in continuous darkness 
pared to the first experiment. Bacterial growth was lower but continued longer before a plateau was reached. The response time of $\mathrm{HNF}$ was also longer and the peaks were less expressed than in the illuminated parallels. This experiment was probably terminated before the HNF peak was reached. Ingestion and clearance rates of HNF were in the same range as measured in the first experiment.

A third experiment was done at Stn 274 under light/ dark incubation. Experimental temperature varied from 20.5 to $21.5^{\circ} \mathrm{C}$. Similar to Stn 239, prey-predator oscillations between bacteria and HNF emerged in the $<10 \mu \mathrm{m}$ pre-screened bottles, and concentrations remained almost unchanged in the unfiltered container (Fig. 4). In contrast to the results obtained at Stn 239 , however, no larger HNF peak was observed in the smallest compartment, and higher HNF concentrations evolved in the $<30 \mu \mathrm{m}$ flask although the final concentration of their potential predators was higher $(18.0 \times$ $10^{2} \mathrm{I}^{-1}$ dinoflagellates $)$ or only slightly lower $\left(2.0 \times 10^{2}\right.$ $1^{-1}$ ciliates) compared to the previous experiments. Ingestion and clearance rates of HNF were similar to the earlier results (Tables 1 to 3 ). Average ingestion rates measured in the first 3 experiments in prefiltered enclosures $(<1 \mu \mathrm{m}$ to $<30 \mu \mathrm{m})$ were $19.7 \pm 9.8$ (SD) bacteria $\mathrm{HNF}^{-1} \mathrm{~h}^{-1}$. Average clearance was 14.6 \pm 9.1 (SD) $n l H_{N F}^{-1} \mathrm{~h}^{-1}$ in the southern area.

The maximal growth rates of bacteria and HNF were similar to the first experiment. It is remarkable, however, that bacterial growth rates increased from the predator-free bottle to the $<10 \mu \mathrm{m}$ and $<30 \mu \mathrm{m}$ treatments (Table 1). Therefore, we conclude that although bacteria were not strictly substrate-limited as indicated by the observed increase in the grazer-free experiment, substrate or nutrient limitation played some role in reducing maximal bacterial growth rates. Growth rates were higher in those bottles where nano-sized algae and protozoa were present. The lower bacterial growth in unfiltered samples is ascribed to grazing control. Thus, this type of response can be characterized by simultaneous substrate and grazing control of bacterial population growth.

\section{Experiments in the northern area}

At Stn 361 in the northern investigation area we found a third type of response to the removal of grazers. According to lower ambient temperatures, samples were incubated at $17^{\circ} \mathrm{C}\left( \pm 1^{\circ} \mathrm{C}\right)$. Bacteria did not grow in either experiment but decreased during the first $24 \mathrm{~h}$ (Fig. 5). After $25 \mathrm{~h}$ some water was added (one third of the original experimental volume) taken from $150 \mathrm{~m}$ depth, which was well below the euphotic depth, to each container. This water was characterized by higher nitrate and nitrite concentrations (>0.2 $\mu \mathrm{mol} \mathrm{l}^{-1}$ ), whereas concentrations of ammonia and phosphate in $150 \mathrm{~m}$ were similarly low as in near-surface waters. Bacteria started growing immediately. The increase levelled off about $16 \mathrm{~h}$ later, $40 \mathrm{~h}$ after the beginning of the experiment. A second addition of deep water after $79 \mathrm{~h}$ and a third one after $133 \mathrm{~h}$ were followed by similar distinct increases of bacterial numbers. The last
Fig. 4. Bacterial and HNF numbers in Expt No. 3 conducted at Stn 274 (L/D incubation)
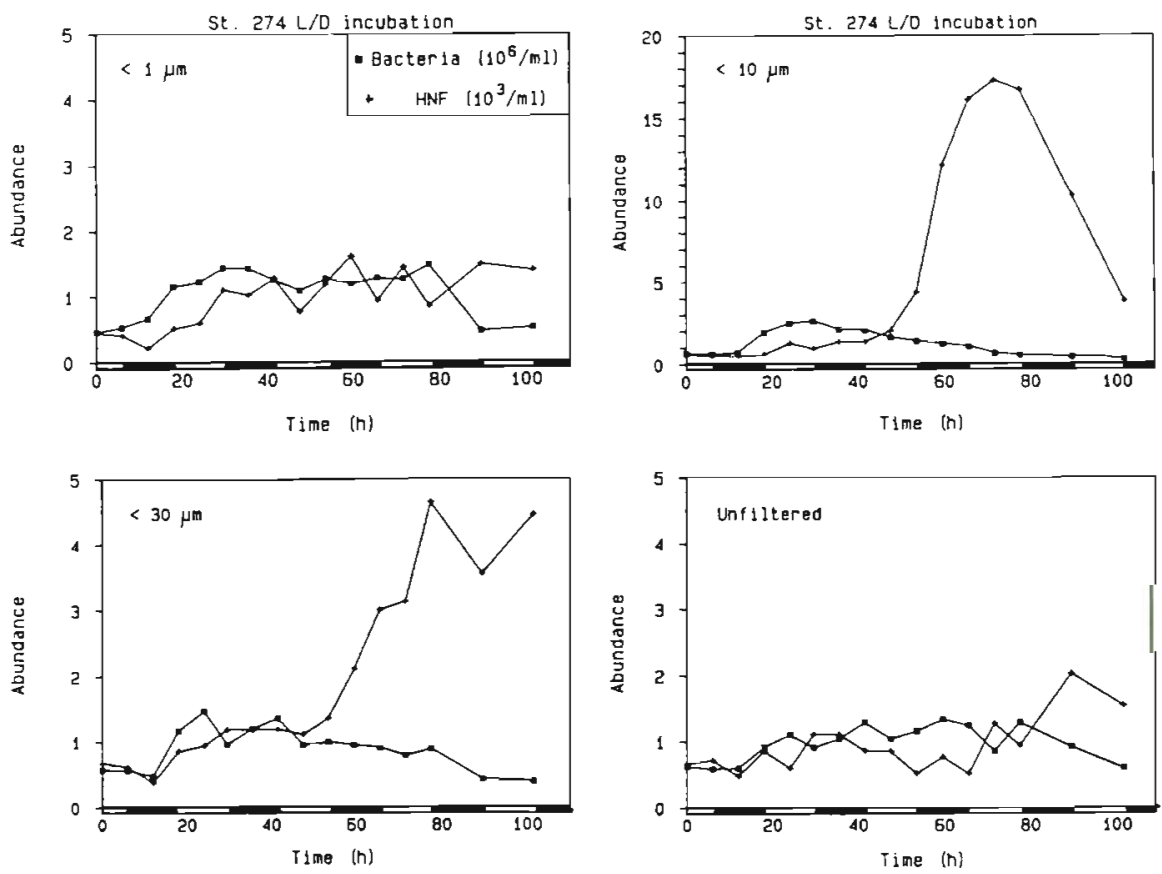

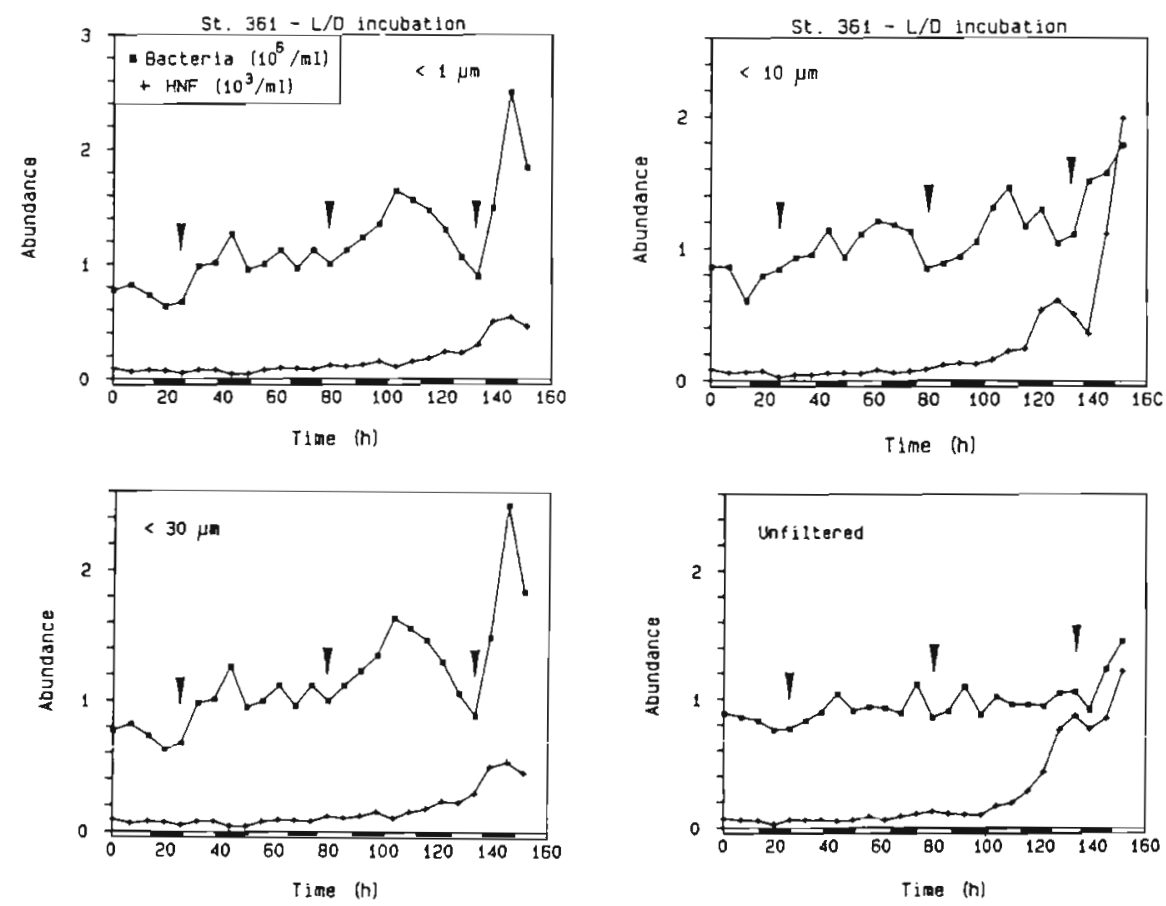

Fig. 5. Bacterial and HNF numbers in Expt No. 4 conducted at Stn 361 (L/D incubation). Arrows indicate the addition of deep water pulse was the most pronounced in all cases. Bacterial growth rates calculated for the 3 periods of exponential increase scattered widely. Growth rates of HNF were unambiguously lower than in the southern study area (Table 1). HNF numbers rose in all enclosures at the end of the incubation period irrespective of the prefiltration. The species composition of HNF was more variable than in the first 3 experiments. Three to four species belonging to the chrysomonads and kinetoplastids reached higher numbers. Choanoflagellates were found sporadically. Ingestion and clearance rates calculated for the HNF community were similar to the other experiments (Table 3 ). Final concentrations of dinoflagellates $\left(2.4\right.$ to $\left.11.0 \times 10^{2} \mathrm{ml}^{-1}\right)$ and ciliates $(1.0$ to $2.8 \times 10^{2} \mathrm{ml}^{-1}$ ) in the $<30 \mu \mathrm{m}$ and unfiltered enclosures were only slightly higher than initial concentrations generally found in the water column. As in the previous experiments, we did not find larger protozoa than HNF in the $<1 \mu \mathrm{m}$ and $<10 \mu \mathrm{m}$ prescreened enclosures.

In contrast to the experiments conducted in the southern study area, the last experiment simulated the natural situation only during the first $24 \mathrm{~h}$ when bacterial numbers decreased and HNF concentrations remained constantly low. Obviously, both bacteria and HNF were strongly nutrient- or substrate-limited. The fast increase of bacteria after the addition of nutrientrich deep water and the beginning HNF peak at the end of the incubation period demonstrated that the majority of the bacterial and HNF populations were not dormant but able to respond quickly to improving environmental conditions.

\section{DISCUSSION}

\section{Microbial food chain}

This paper presents the first results of prey-predator interactions of pelagic microorganisms in the open North Atlantic. Our results confirm earlier findings of tight coupling among the different components of the microbial loop in oligotrophic marine environments (Rassoulzadegan \& Sheldon 1986, Hagström et al. 1988, Wikner \& Hagström 1988, Weisse 1989). Except for one study from the Red Sea (Weisse 1989), the other investigations were all performed in coastal areas.

Within the microbial loop a linear food chain consisting of up to 5 food levels appears to be the dominant pathway of organic matter transfer (Azam et al. 1983, Sheldon et al. 1986, Wikner \& Hagström 1988). The results we obtained indicate that bacteria were primarily grazed by HNF which in turn were cropped mainly by organisms in the $10-30 \mu \mathrm{m}$ size range. This size class was dominated by small ciliates and dinoflagellates. At Stn 274, however, a HNF peak developed in the $<30$ $\mu \mathrm{m}$ container which did not occur in the unfiltered enclosure. Therefore, protozoa larger than $30 \mu \mathrm{m}$ may also feed on HNF. We did not find crustacean instars or larger metazoans in the prescreened experiments. 
Among dinoflagellates, the genera Gymnodinium, Gyrodinium, and Cochlodinium, which comprise many heterotrophic species, were prominent. Yet, an unequivocal discrimination between autotrophic and heterotrophic dinoflagellates was not possible in the Lugol-fixed samples.

\section{Control of bacterial population growth and abundance}

In both investigation areas numbers of bacteria and HNF remained almost constant in situ during the period of observation. Therefore, we conclude that production and loss processes were approximately in balance. Under such equilibrium conditions, the bacterial population size is, according to Eq. (1), solely determined by predation. The growth rate of the bacteria and the population size of the HNF, however, are determined by the substrate supply which is implicit in the function $\mu(x)$. Although growth and losses due to predation act antagonistically, they are linked in various ways. It is well known that bacterivorous protozoa have a positive effect on bacterial growth rates (Andersson et al. 1986, Sherr et al. 1988). The mechanisms by which protozoan grazing stimulates bacterial activity might be direct or indirect (Sherr et al. 1988, Stone 1990). If part of the bacterial population is removed by grazing and the substrate supply is not altered, the relative rate of supply will have increased for the remaining part of the population. This effect will be enhanced because protozoa excrete small quantities of utilizable dissolved organic matter (UDOM; Taylor et al. 1985, Andersson et al. 1986) and inorganic nutrients. Indirect effects might stimulate bacterial activity by increasing the pool of UDOM via 'sloppy feeding' (Lampert 1978) on algae and bacteria or by enhancing phytoplankton production as a consequence of grazing (Sherr et al. 1988). In our study it is impossible to differentiate between these different feedback mechanisms that led to enhanced bacterial growth in some of the enclosures where grazers were present.

The population sizes of the HNF and higher trophic levels are also a function of the substrate supply of the first level, i.e. in the present study bacteria (cf. Eqs. 1 \& 2 ). This cascading effect and the positive feedback mechanisms on bacterial growth rates via grazing might render the question of bottom-up versus topdown control a pseudoproblem. Attempts to model the simultaneous impact of substrate supply and grazing have been made by Billen et al. (1980) and Wright (1988a, b) using simplified assumptions. Although one or the other control mechanism will prevail temporarily, the feedback mechanisms will occur constantly since grazers are always present in the natural environ- ment. Accordingly, simultaneous substrate and grazing control which we identified in the third experiment is probably most common in natural waters. We found this type of response also in the North Sea, an adjacent part of the North Atlantic, during the late phytoplankton spring bloom (Weisse \& Scheffel-Möser unpubl.). Similarly, Kirchman (1990) reported that even though additions of dissolved free amino acids stimulated bacterial production by as much as 4 -fold, bacterial abundance did not change in the subarctic Pacific. Kirchman concluded that grazing prevented any increase in bacterial abundance.

\section{Growth, grazing and clearance rates of HNF}

Growth and grazing rates calculated for HNF from the experimental results are in the range of values reported mainly from coastal or freshwater environments. Bacterial consumption rates assessed with different methods and various species range from several up to about 80 bacteria $\mathrm{HNF}^{-1} \mathrm{~h}^{-1}$, clearance rates from 0.2 to $100 \mathrm{nl} \mathrm{HNF}^{-1} \mathrm{~h}^{-1}$ (Sherr et al. 1986, Weisse 1989, 1990 and references therein). In various oceanic and limnic environments, the average consumption rate was about 15 bacteria $\mathrm{HNF}^{-1} \mathrm{~h}^{-1}$ (Weisse 1991) which is close to the mean rate $\left(19.7\right.$ bacteria $\mathrm{HNF}^{-1}$ $\mathrm{h}^{-1}$ ) estimated from the enclosure experiments discussed here. The mean clearance rate, $15 \mathrm{nl} \mathrm{HNF}^{-1} \mathrm{~h}^{-1}$. is remarkably similar to the value of $17 \mathrm{nl} \mathrm{HNF}^{-1} \mathrm{~h}^{-1}$ reported by Andersen \& Fenchel (1985) from similar experiments conducted with bacteria and flagellates isolated from the Danish Limfjord. The corresponding mean ingestion rates measured by Andersen \& Fenchel were 57 bacteria $\mathrm{HNF}^{-1} \mathrm{~h}^{-1}$. As already mentioned, both rates might have been slightly overestimated because they were calculated at the first bacterial peak and thus did not consider a potential time-lag of the response of HNF to the increase of the bacterial populations. The results reported in Table 3 suggest that this effect, which is caused by physiological adaptation of formerly starved cells to improving environmental conditions, was more important in the present study. Since the initial bacterial concentration was low, temporary starvation of HNF in these oligotrophic waters appears to be likely. The specific clearance rate of HNF was about $5 \times 10^{5}$ body volumes $h^{-1}$, a value which agrees well with previous results measured in oligotrophic marine environments (Weisse 1989 and references therein).

The average maximum growth rate of HNF was $0.102 \mathrm{~h}^{-1}$ and the corresponding bacterial consumption rate 19.7 bacteria $\mathrm{HNF}^{-1} \mathrm{~h}^{-1}$. By dividing the growth rate by the ingestion rate we obtain the per capita growth yield, $5.2 \times 10^{-3}$ per bacterium. Hence one 
average HNF would need 193 bacteria in order to divide.

\section{Ecological significance of HNF grazing}

Some caution is needed when extrapolating results obtained by the size-fractionation technique to the natural environment. Although we did not observe pronounced prey-predator oscillations at the sampling locations, we cannot rule out that minor fluctuations occurred in situ. Therefore, the particular phase of the natural cycle at the time of sampling might have had an effect on the outcome of our incubation experiments. Likewise, regeneration of bacterial substrates and nutrients was probably lower in the enclosures than in the water column. Bearing these restrictions in mind, we can roughly evaluate the ecological significance of HNF grazing in those oligotrophic parts of the North Atlantic.

If the mean clearance rate of $15 \mathrm{nl} \mathrm{HNF}^{-1} \mathrm{~h}^{-1}$ is extrapolated to the natural environment using the average in situ concentrations, between $28 \%$ of the water column in the southern area and $31 \%$ in the northern area is cleared of bacteria by HNF per day. However, this clearance rate was estimated for cultured and well-fed flagellates. At the beginning of the enclosure experiments the mean biovolume of HNF was lower by a factor of 2 to 4 in the 3 larger fractions (cf. Table 2). The increase of the average HNF volume is a result of both a shift towards larger HNF which were rarely seen in the initial samples and of enlarged individual cell size. Therefore, the in situ clearance rate is probably overestimated. This effect is most likely lower than the increase in the average biovolume because larger flagellates tend to have lower volumespecific clearance rates than smaller species (Fenchel 1987). If we assume that the in situ clearance was half of the experimental rate, about $15 \%$ of the water column is filtered clear by the HNF per day which is closer to the $20 \%$ filtering rate estimated for the Limfjorden (Fenchel 1982b). Hence, if bacteria would not grow, bacterial biomass would be consumed by HNF grazing within 6 to $7 \mathrm{~d}$. In the southern area where bacterial growth appeared largely to be balanced by grazing, bacterial doubling time should have been similar. Assuming an average bacterial carbon content of $15 \mathrm{fg} \mathrm{cell}^{-1}$ (Simon \& Azam 1989) and the mean in situ concentration of $0.52 \times 10^{6}$ bacteria $\mathrm{ml}^{-1}$, bacterial net production was about $120 \mathrm{mg} \mathrm{C} \mathrm{m}^{-2} \mathrm{~d}^{-1}$ averaged over the upper $100 \mathrm{~m}$ of the water column. Primary production measured as ${ }^{14} \mathrm{C}$ incorporation ranged from 100 to $1100 \mathrm{mg} \mathrm{C} \mathrm{m}^{-2} \mathrm{~d}^{-1}$. The mean value was slightly more than $400 \mathrm{mg} \mathrm{C} \mathrm{m}^{-2} \mathrm{~d}^{-1}$ (Jochem 1990). Accordingly, bacterial production equalled about $30 \%$ of primary production, a value which is typical for oceanic environments (Cole et al. 1988). Unfortunately, no independent measurements of bacterial production using tracer techniques are available for the area and time period under discussion. Considering the assumptions involved, our calculation is nothing more than an educated guess.

\section{Conclusions}

Our results revealed that the mode of control of microbial growth rates and abundances can be different even in oligotrophic areas where there is no apparent difference in nutrient status, primary production, bacterial or grazer concentration. Hence a prediction of the prime factor controlling bacterial abundance, growth and production in the oligotrophic parts of the oceans at a given time and location seems to be impossible at present. Since the processes of growth and losses due to grazing are ultimately linked, the problem of bottom-up versus top-down control might become a non-issue.

Bacteria and their major predators are closely coupled, and predator-prey oscillations occur, if they emerge at all, at time scales of only a few days. Steady state conditions between growth and grazing appeared at even shorter time scales. Therefore, caution is needed in extrapolating results derived from theoretical models which assume steady state conditions to the natural environment.

Acknowledgements. We thank captain $\mathrm{M}$. Kull and the crew of RV 'Meteor' for their kind cooperation. The efforts of the 2 chief scientists, B. Zeitzschel and R. Peinert, are gratefully acknowledged. $M$. Simon and 3 anonymous reviewers provided constructive comments on an earlier version of the manuscript. This study was financially supported by the Volkswagenwerk Foundation ('Wettbewerb Biowissenschaften', grant I/63 699).

\section{LITERATURE CITED}

Andersen, P., Fenchel, T. (1985). Bacterivory by microheterotrophic tlagellates in seawater samples. Limnol. Oceanogr. 30: 198-202

Andersson, A., Larsson, U., Hagström, A. (1986). Size-selective grazing by a microflagellate on pelagic bacteria. Mar. Ecol. Prog. Ser. 33: 51-57

Azam, F., Fenchel, T., Field, J. G., Gray, J. S., Meyer-Reil, L.A., Thingstad, F. (1983). The ecological role of watercolumn microbes in the sea. Mar. Ecol. Prog. Ser. 10: $257-263$

Bergh, O., Borsheim, K. Y., Bratbak, G., Heldal, M. (1989). High abundance of viruses found in aquatic environments. Nature, Lond. 340: 467-468

Billen, G., Joiris, C., Wijnant, J., Gillain, G. (1980). Concentration and microbiological utilization of small organic molecules in the Scheldt Estuary, the Belgian coastal zone of the North Sea and the English Channel. Estuar coast. mar. Sci. 11: 279-294 
Bratbak, G., Heldal, M., Norland, S., Thingstad, T. F. (1990). Viruses as partners in spring bloom microbial trophodynamics. Appl. environ. Microbial 56: 1400-1405

Cole, J. J., Findlay, S., Pace, M. L. (1988). Bacterial production in fresh and saltwater ecosystems: a cross-system overview. Mar. Ecol. Prog. Ser. 43: 1-10

Ducklow, H. W. (1983). Production and fate of bacteria in the oceans. Bioscience 33: 494-501

Fenchel, T. (1982a). Ecology of heterotrophic microflagellates. III. Adaptations to heterogeneous environments. Mar. Ecol. Prog. Ser. 9: 25-33

Fenchel, T. (1982b). Ecology of heterotrophic microflagellates. IV. Quantitative occurrence and importance as bacterial consumers. Mar. Ecol. Prog. Ser. 9: 35-42

Fenchel, T. (1987). Ecology of protozod. Science Tech/ Springer, Madison

Fuhrman, J. A., Sleeter, T. D., Carlson, C. A., Proctor, L. M. (1989). Dominance of bacterial biomass in the Sargasso Sea and its ecological implications. Mar. Ecol. Prog. Ser. 57: $207-217$

Güde, H. (1986). Loss processes influencing growth of planktonic bacterial populations in Lake Constance. J. Plankton Res. 8: 795-810

Güde, H. (1989). The role of grazing on bacteria in plankton succession. In: Sommer, U. (ed.) Plankton ecology: succession in plankton communities. Springer, Berlin, p. 337-364

Hagström, A., Azam, F., Andersson, A., Wikner, J., Rassoulzadegan, F. (1988). Microbial loop in an oligotrophic pelagic marine ecosystem: possible roles of cyanobacteria and nanoflagellates in the organic fluxes. Mar. Ecol. Prog. Ser. 49: 171-178

Jochem, F. (1990). Zur Struktur und Dynamik autotropher Untraplankton-Gemeinschaften in marinen WarmwasserÖkosystemen. Ber. Inst. Meereskde Kiel 195: 1-220

Joint, I. R., Owens, N. J. P., Pomroy, A. J. (1986). Seasonal production of photosynthetic picoplankton and nanoplankton in the Celtic Sea. Mar. Ecol. Prog. Ser. 20: 113-118

Kirchman, D. L. (1990). Limitation of bacterial growth by dissolved organic matter in the subarctic Pacific. Mar. Ecol. Prog. Ser. 62: 47-54

Kuuppo-Leinikki, P. (1990). Protozoan grazing on planktonic bacteria and its impact on bacterial population. Mar. Ecol. Prog. Ser. 63: 227-238

Lampert, W. (1978). Release of dissolved organic carbon by grazing zooplankton. Limnol. Oceanogr. 23: 831-834

McManus, G. B., Fuhrman, J. A. (1988). Control of marine bacterioplankton populations: measurement and significance of grazing. Hydrobiologia 159: 51-62

Nagata, T. (1990). Contribution of picoplankton to the grazer food chain in Lake Biwa. In: Tilzer, M. M., Serruya, C. (eds.) Large lakes: ecological structure and function. Springer/Science Tech. Publ., Berlin, p. 526-539

Pace, M. L. (1988). Bacterial mortality and the fate of bacterial production. Hydrobiologia 159: 41-49

Porter, K. G., Feig, Y. S. (1980). The use of DAPI for identifying and counting aquatic microflora. Limnol. Oceanogr. 25: 943-948.

Proctor, L. M., Fuhrman, J. A. (1990). Viral mortality of marine bacteria and cyanobacteria. Nature, Lond. 343: 60-62
Rassoulzadegan, F., Sheldon, R. W. (1986). Predator-prey interactions of nano-zooplankton and bacteria in an oligotrophic marine environment. Limnol. Oceanogr. 31: 1010-1021

Sheldon, R. W., Nival, P., Rassoulzadegan, F. (1986). An experimental investigation of a flagellate-ciliate-copepod food chain with some observations relevant to the linear biomass hypothesis. Limnol. Oceanogr. 31: 184-188

Sherr, B. F., Sherr, E. B., Andrew, T. L., Fallon, R. D., Newell, S. Y. (1986). Trophic interactions between heterotrophic Protozoa and bacterioplankton in estuarine water analyzed with selective metabolic inhibitors. Mar. Ecol. Prog. Ser. 32: 169-179

Sherr, B. F., Sherr, E. B., Hopkinson, C. S. (1988). Trophic interactions within pelagic microbial communities: indications of feedback regulation of carbon flow. Hydrobiologia 159: $19-26$

Simon, M., Azam, F. (1989). Protein content and protein synthesis rates of planktonic marine bacteria. Mar. Ecol. Prog. Ser. 51: 201-213.

Stone, L. (1990). Phytoplankton-bacteria-protozoa interactions: a qualitative model portraying indirect effects. Mar. Ecol. Prog. Ser. 64: 137-145

Taylor, G. T. R., Iturriaga, R., Sullivan, C. W. (1985). Interactions of bacterivorous grazers and heterotrophic bacteria with dissolved organic matter. Mar. Ecol. Prog. Ser. 22: 129-141

Weisse, T. (1989). The microbial loop in the Red Sea: dynamics of pelagic bacteria and heterotrophic nanoflagellates. Mar. Ecol. Prog. Ser. 55: 241-250

Weisse, T. (1990). Trophic interactions among heterotrophic microplankton, nanoplankton, and bacteria in Lake Constance (FRG). Hydrobiologia 191-111-122

Weisse, T. (1991). The microbial food web and its sensitivity to eutrophication and contaminant enrichment: a crosssystem overview. In: Schiewer, U. (ed.) Eutrophication of the Baltic Sea. Int. Revue ges. Hydrobiol., Spec. Vol. (in press)

Weisse, T., Schweizer, A. (1991). Seasonal and interannual variation of autotrophic picoplankton in a large prealpine lake (Lake Constance). Verh. Int. Verein. Limnol. 24: in press

Wikner, J., Hagström, A. (1988). Evidence for a tightly coupled nanoplanktonic predator-prey link regulating the bacterivores in the marine environment. Mar. Ecol. Prog. Ser. 50: $137-145$

Williams, P. J. LeB. (1981). Incorporation of microheterotrophic processes into the classical paradigm of the planktonic food web. Kieler Meeresforsch., Sonderh. 5: 11-28.

Wright, R. T. (1988a). Methods for evaluating the interaction of substrate and grazing as factors controlling planktonic bacteria. Arch. Hydrobiol. Beih. Ergebn. Limnol. 31: 229-242

Wright, R. T. (1988b). A model for short-term control of the bacterioplankton by substrate and grazing. Hydrobiologia 159: 111-117

Wright, R. T., Coffin, R. B. (1984). Measuring microzooplankton grazing on planktonic marine bacteria by its impact on bacterial production. Microb. Ecol. 10: 137-149

Manuscript first received: September 4, 1990

Revised version accepted: February 22, 1991 